\title{
Mycoremediation of Petroleum Contaminated Soils: Progress, Prospects and Perspectives
}

${ }^{1}$ Dickson, Udeme John; ${ }^{2}$ Coffey, Michael; ${ }^{1}$ Mortimer, Robert John George; ${ }^{1}$ Di Bonito, Marcello and $1_{\text {Ray, Nicholas }}$

${ }^{1}$ School of Animal, Rural and Environmental Sciences, Nottingham Trent University, Brackenhurst, Southwell, Nottinghamshire NG25 0QF, United Kingdom

${ }^{2}$ Department of Chemistry \& Forensic Sciences, School of Sciences, Nottingham Trent University, Clifton, NG11 8NS, Nottingham, United Kingdom

Contact: uj.dickson@yahoo.com

\begin{abstract}
Mycoremediation, an aspect of bioremediation, has been investigated for some decades. However, there seems to be little progress on its commercial application to petroleum-contaminated soils despite some promising outcomes. In this review, mycoremediation is examined to identify development, limitations and perspectives for its optimal utilization on petroleum-contaminated soils. Mycoremediation agents and substrates that have been used for the treatment of petroleum contaminated soils have been identified, application methods discussed, recent advances highlighted and limitations for its applications accentuated. Possible solutions to the challenges in applying mycoremediation to petroleum-contaminated soils have also been discussed. From this review, we conclude that for optimal utilization of mycoremediation of petroleum-contaminated soils, ideal environmental, edaphic and climatic factors of a typical contaminated site must be incorporated into the approach from first principles. Development of application procedures that can easily translate laboratory results to field applications is also required.
\end{abstract}

\section{KEYWORDS: mycoremediation, fungi, crude oil, soil-contamination}

\section{Introduction}

Mycoremediation offers an alternative environmentally friendly technique for remediation of contamination in environmental matrices ${ }^{1-4}$. It entails the use of fungi and has been applied to both soil and water 5,6 . The technique has several advantages over other bioremediation, physical and chemical methods. Apart from cost and technical ease, the ubiquitous nature of most fungi species could afford widespread applications in different regions of the world 7,8 . Leonardi ${ }^{9}$ and Rahman ${ }^{10}$ stated that mycoremediation seems to be the safest means of soil remediation in terms of ecological impact and Human health. This is because most organic contaminants are degraded rather than extracted, which reduces the risk of bioaccumulation and transfer of pollutants into the food chain11-13. According to Asamudo14 and Adenipekun 15 mycoremediation is unique even among other biological techniques such as 
bacterial, because there is no requirement for pre-conditioning to a particular pollutant. Asamudo 14 further stated that in mycoremediation, the efficiency is not limited to specific pollutant concentrations. It is, therefore, necessary to examine why the technique of mycoremediation has not been maximized for clean-up of petroleum-contaminated soils and to identify possible solutions to the challenges that may arise.

Although there are several reviews on mycoremediation, none is tailored specifically to that of petroleum-contaminated soils. This review evaluates the development, limitations and perspectives of mycoremediation of petroleum-contaminated soils. It is specifically carried out to elucidate prospects that could further improve the utilization of the technique for the cleanup of petroleum-contaminated soils.

\section{Fungi and Fungal spawns}

The kingdom Fungi, distinguished from plants by the possession of chitin in their cell walls, consists of both unicellular and multicellular organisms such as yeast and moulds, as well as macroscopic types such as mushrooms 16,17. Fungi are classified based on their life cycles, presence or structure of their fruiting body, or the arrangement and type of reproductive cells (spores) they produce 18 . Principally, there are three major groups of fungi. These are multicellular filamentous moulds, macroscopic filamentous fungi that form large fruiting bodies (mushrooms) and single-celled microscopic fungi such as yeasts ${ }^{19}$. Fungi are also broadly classified either as microfungi or macrofungi. The two are distinguished only by the presence of a large (visible), multicellular fruiting body in macrofungi. Macrofungi are generally referred to as mushrooms. Microfungi could be unicellular such as yeast, or multicellular such as moulds. The body of a typical fungus consists of a collection of hyphae which is referred to as the mycelium. A hypha is a long, branching filamentous structure consisting of one or more cells surrounded by a tubular cell wall which extends through the substrate in which the fungi grow 20 . Hyphae have an average diameter of $4-6 \mu \mathrm{m}$ and serve as the vegetative part of the organism ${ }^{19}$. The hyphae may be divided by internal cross walls, the Septa, into cells. Typically, Septa are perforated by pores large enough for ribosomes, mitochondria and sometimes nuclei to flow between cells $16-19$. 
For commercial propagation of mushrooms, mushroom spawns are used 21 . The propagative part of a fungus is the mycelium (a collection of hyphae). Mushroom spawns refer to any material which has been inoculated with mycelium for the propagation of mushrooms 22 . The spawn is used to transfer the fungal mycelium onto any material (substrate) from which the mushroom can grow. Although mushrooms can grow straight from spawn without a substrate, most times this is not ideal 23 . It has been demonstrated that a small quantity of mushroom spawn can inoculate a much greater amount of substrate resulting in better mushroom growth and yield compared to using the spawn alone 24 . Mushroom spawns are named according to the material used for inoculation of the fungal mycelia. Thus, sawdust spawn consists of a sterilized sawdust that has been inoculated with mycelium, while grain spawn is made of a sterilized grain inoculated with spores or a sterile culture of mycelium. Examples of grains that have been used for grain spawns are rye, rice, corn and wheat. Other types of spawns are plug or dowel spawn, woodchip spawn, straw spawn and liquid spawn (water enriched with mushroom spores or mycelia slurry) 25 .

\section{Factors affecting mycoremediation}

The efficiency of mycoremediation is affected by factors such as temperature, sunlight, oxygen level, nutrients and moisture content 26 . It has been demonstrated that mycoremediation is optimal at temperatures of $25-30^{\circ} \mathrm{C} 27$. Aguilarivera 28 reported that $70 \%$ relative humidity is ideal for mycoremediation with $P$. ostreatus. According to Brady 29 a carbon-nitrogen ratio of 10 in soil is optimal. Nutrient requirement is usually maintained using both organic and inorganic manures 27 . Gueren 30 demonstrated that a combination of mycoremediation with compost resulted in up to $50 \%$ increase in the remediation efficiency of polycyclic aromatic hydrocarbons (PAHs). The addition of compost also aids temperature optimization during the process 6 . Amjad ${ }^{31}$ further listed factors affecting mycoremediation efficiency to include environmental and genetic factors such as $\mathrm{pH}$, ecology, type of substrate, enzyme type and mycelium age. Das 32 reported that nutrients such as nitrogen and phosphorus could become limiting factors. Mushroom biomass content, length of remediation process and type of substrates as well as mobilizing agents are also known to 
affect the efficiency of mycoremediation 33 . Other factors include the life cycle of fungal agents, fungal species, soil geochemistry as well as surface active and chelating agents 34,35 .

\section{Effects of bioavailability on mycoremediation}

Petroleum contaminants, particularly the semi-volatiles, are hydrophobic ${ }^{36}$. Thus, solubility and bioavailability are important factors in bioremediation of petroleum-contaminated soils. Boopathy 37 stated that the rate of contaminant conversion during bioremediation depends on their uptake and metabolism rate and the rate of contact with the cells of the organism. Manning 38 reported that activities which result in the homogenous spread of contaminants in soils can drastically stimulate their biodegradation. Singh 39 demonstrated that bioavailability of organic contaminants decreases with time. In a study on the degradation of DDT in soil, it was found that there was a substantial decrease in the degradation rate with time even in the presence of aged DDT. According to Boopathy 37 , several physicochemical processes such as sorption and desorption, diffusion, and dissolution influence contaminants bioavailability. Thus, these factors must be considered in planning for mycoremediation of petroleum contaminated soils. The use of surface-active agents can help overcome the problem of contaminants bioavailability during remediation of petroleum-contaminated soils 37 .

\section{Effects of Temperature on mycoremediation}

Temperature generally plays a critical role in bioremediation processes 40 . It has been demonstrated that the rate of degradation of organic contaminants is comparably higher at elevated temperatures 41 . Higher rates of degradation of organic contaminants are also reported in tropical soils compared to soils from temperate regions 42,43 . Dimond 44 stated that temperature affects the half-life of organic contaminants which increases with lowering temperatures. Hong 45 demonstrated that a temperature range of $20-40{ }^{\circ} \mathrm{C}$ was optimal for degradation of the contaminant fenitrothion. Siddique 40 further demonstrated that the highest degradation of Hexachlorocyclohexane in water and a soil slurry was achieved at an incubation temperature of $30^{\circ} \mathrm{C}$. 


\section{Effects of $\mathrm{pH}$ on mycoremediation}

The degradation of organic contaminants in soil is favoured by high $\mathrm{pH}$ because of increased solubility 46 . Owen 42 demonstrated that alkaline soil $\mathrm{pH}$ resulted in faster degradation of organic contaminants compared to those carried out in acidic soil. According to Andrea47, the degradation of organic contaminants is inhibited at low soil pH of 4.5 to 4.8 . Nash 48 in a study of effects of $\mathrm{pH}$ on stability of DDT, observed that maximal degradation in both moist and dry soils were obtained at $\mathrm{pH}$ values above 7 . Hong 45 reported a bioremediation of fenitrothion-contaminated soil using Burkholderia sp. FDS-1 with an optimal degradation at a slightly alkaline $\mathrm{pH}$ of 7.5. Thus, $\mathrm{pH}$ is one of the factors that should be considered in mycoremediation of petroleum contaminated soils.

\section{Effects of Relative humidity on mycoremediation}

For mycoremediation of contaminated soils, relative humidity is generally maintained at above $60 \% 49,50$. A study carried out by Xiao 49 utilised a relative humidity of $70 \%$, that by Migliore 50 was $60 \%$ while the relative humility in $\operatorname{Singh}^{51}$ was between $60-70 \%$. Higher relative humidity values of up to $85-95 \%$ have also been reported ${ }^{52}$. Seidu 53 reported that mushroom growth and fruiting is favoured by a relative humidity of $70-80 \%$.

\section{Fungal types used for mycoremediation of petroleum contaminated soils}

Different species of fungi have been used for remediation of petroleum-contaminated soils (Table 1). These include microfungi such as Arbuscular mycorrhiza and yeast $54-56$ as well as Penicillium and Aspergillus species 57,58. Mycoremediation with macrofungi (mushrooms) is also known 15,59 . Abioye 56 reported degradation of crude oil by the yeast Saccharomyces cerevisiae isolated from a fermented local juice (Zobo). The yeast was used to inoculate a sterile mineral salt media containing $1 \mathrm{~g}$ of crude oil maintained at $30^{\circ} \mathrm{C}$ for 28 days. Obire 60 established that microfungal communities were actively involved in remediation potentials of cow and poultry manure on petroleum contaminated soils. In the study, isolated yeasts and moulds from cow manure used for remediation of the petroleum contaminated soils include Alternaria sp., Aspergillus sp., Cephalosporium sp., Cladosporium sp., Geotrichum sp., Monilia sp., Mucor sp., Penicillium sp., Rhizopus sp., Sporotrichum sp., Thamnidum sp., Candida sp., 
Rhodotorula sp. and Torulopsis sp. Yeast such as Saccharomyces spp has also been demonstrated to transform PAHs to simpler and non-toxic forms 61 .

One significant class of fungi with demonstrated mycoremediation of petroleum contaminated soils are the ligninolytic mushrooms such as white rot fungi $62-64$. Lebo 65 and Fetzer 66 stated that the ability of white rot fungi to degrade recalcitrant organic pollutants stems from the fact that these mushrooms naturally feed on and degrade lignin, a substance

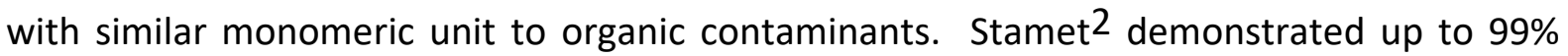
degradation in a large-scale study of naturally diesel-contaminated soils with initial concentrations of 20,000 parts per million of PAHs after 8 weeks using the white rot mushroom P. ostreatus. Kristanti 67 established that up to $93 \%$ degradation of crude oil in the soil can be obtained using the white rot mushroom Polyporus sp. S133 pre-grown on wood meal.

Mycoremediation by mushrooms other than white rot have also been reported. These include brown rot fungi such as Ganoderma species, and edible (button) mushrooms such as Agaricus species (which grows naturally on soils)35,68. It has been demonstrated that the litterdecomposing mushroom Stropharia coronilla, can metabolise PAHs compounds such as benzo[a]pyrene (BaP) at an initial concentration of $200 \mu \mathrm{M}$ and this activity can be increased up to 12 times in presence of supplementary $\mathrm{Mn}^{2+}$. Mohammadi-Sichani69 established that the litter decomposing mushroom A. bisporus can yield a higher ability to degrade total petroleum hydrocarbons in soils than white rot mushroom such as Pleurotus ostreatus and Ganoderma lucidum. 
Table 1: Fungal types used for mycoremediation of petroleum contaminated soils

\begin{tabular}{|c|c|c|c|c|c|}
\hline $\mathrm{S} / \mathrm{N}$ & STUDIES & FUNGI SPECIES & EXPERIMENT DESIGN & $\begin{array}{l}\text { CLIMATIC } \\
\text { REGION }\end{array}$ & OUTCOME \\
\hline 1. & Adenipekun 70 & $\begin{array}{l}\text { 1. Pleurotus pulmonarius } \\
\text { 2. Pleurotus ostreatus } \\
\text { (All macroscopic) }\end{array}$ & $\begin{array}{l}\text { 1. Laboratory /glasshouse Scale: } 2 \text { months } \\
\text { 2. Artificially contaminated soils (composition: } 0,10,20 \text { or } 30 \% \text { ) with spent } \\
\text { cutting fluid-SCF and fresh cutting fluids-FCF } \\
\text { 3. Target contaminants: } 16 \text { priority PAHs } \\
\text { 4. Solvent for extraction: Hexane, Dichloromethane (3:1). } \\
\text { 5. Method of application: Layering growing substrates and active spawn on } \\
\text { top of soil }\end{array}$ & Tropical climate & $\begin{array}{l}\text { Overall range of PAHs degradation by } P \text {. } \\
\text { pulmonarius inoculated on FCF contaminated soil } \\
\text { was } 17.3 \text { to } 27.3 \% \text {, while for } P \text {. ostreatus } \\
\text { inoculated soil was } 69.0 \text { to } 99.07 \% \text { at different } \\
\text { contamination levels. } \\
\text { Overall PAHs degradation for } P \text {. pulmonarius and } \\
\text { P. ostreatus inoculated on SCF ranged from } 27.4 \text { to } \\
57.4 \% \text { and from } 37.8 \text { to } 45.2 \% \text {, respectively. }\end{array}$ \\
\hline 2. & Nicholas 71 & $\begin{array}{ll}1 . & \text { Heterobasidion annosum } \\
2 . & \text { Resinicium bicolor } \\
& \text { (All macroscopic) }\end{array}$ & $\begin{array}{ll}\text { 1. } & \text { Laboratory /glasshouse Scale: } 36 \text { days } \\
\text { 2. } & \text { Artificially contaminated soils with diesel ( } 3.5 \text { and } 7.0 \%) \\
\text { 3. } & \text { Target contaminants: TPHs } \\
\text { 4. } & \text { Solvent for extraction: Dichloromethane } \\
\text { 5. } & \text { Method of application: prepared mushroom spawn (rice grain colonised } \\
& \text { with fungi- substrates) were transferred to and mixed with soil } \\
\end{array}$ & $\begin{array}{l}\text { Temperate } \\
\text { Climate }\end{array}$ & $\begin{array}{l}\text { ANOVA showed significant decrease in TPHs over } \\
\text { time. }\end{array}$ \\
\hline 3. & Young $^{72}$ & $\begin{array}{ll}\text { 1. } & \text { Irpex lacteus } \\
\text { 2. } & \text { Trichaptum biforme } \\
\text { 3. } & \text { Phlebia radiata } \\
\text { 4. } & \text { Trametes versicolor } \\
\text { 5. } & \text { Pleurotus ostreatus } \\
& \text { (All macroscopic) }\end{array}$ & $\begin{array}{l}\text { 1. Laboratory /glasshouse Scale: } 180 \text { days } \\
\text { 2. Artificially contaminated soil samples were used } \\
\text { 3. Principal substrate: white pine (Pinus strobus) sawdust was used for } \\
\text { Irpex lacteus while others were grown on wheat bran and sawdust, } \\
\text { which was properly moistened. } \\
\text { 4. } 20 \mathrm{~g} \text { of Bunker } \mathrm{C} \text { oil was added to each substrate, which were then } \\
\text { maintained at } 27^{\circ} \mathrm{C} \text { for } 180 \text { days } \\
\text { 5. Target contaminants: TPHs and PAHs } \\
\text { 6. Solvent for extraction: Methylene Chloride }\end{array}$ & $\begin{array}{l}\text { Temperate } \\
\text { Climate }\end{array}$ & $\begin{array}{l}\text { Average degradation efficiency between C10 and } \\
\text { C14 alkanes was observed to be } 98.1 \% \text { and } 48.6 \% \text {, } \\
\text { respectively after } 180 \text { days. } \\
\text { Highest efficiency was obtained for P. ostreatus } \\
\text { against Phenanthrene (94.9\%) after } 180 \text { days }\end{array}$ \\
\hline 4. & El Hanafy 58 & $\begin{array}{l}\text { 1. } \\
\text { Aspergillus niger } \\
\text { 2. Penicillium commune } \\
\text { (all microscopic) }\end{array}$ & $\begin{array}{l}\text { 1. Laboratory /glasshouse Scale: } 2 \text { weeks } \\
\text { 2. Crude oil samples were used } \\
\text { 3. Germinating fungi pre-cultured for one week were transferred to } 100 \mathrm{ml} \\
\text { of Bushnell Haas media then to } 500 \mathrm{ml} \text { conical flask containing } 1 \% \text { crude } \\
\text { oil, } 0.1 \% \text { V/V Tween } 80 \text { and } 0.016 \mathrm{mg} / \mathrm{ml} \text { of redox oxidation. The flask } \\
\text { was incubated for } 2 \text { weeks before assessment. }\end{array}$ & $\begin{array}{l}\text { Temperate } \\
\text { climate }\end{array}$ & $\begin{array}{l}>\quad \text { Aspergillus niger degraded } 54 \% \text { of crude oil, while } \\
>\quad \text { Penicillium commune degraded } 48 \%\end{array}$ \\
\hline 5. & Flayyih $^{73}$ & $\begin{array}{l}\text { 1. Aspergillus niger, } \\
\text { 2. Aspergillus fumigatus, } \\
\text { 3. Fusarium solani } \\
\text { 4. Peniclllium funiculosum } \\
\quad \text { (all microscopic) }\end{array}$ & $\begin{array}{l}\text { 1. Laboratory /glasshouse Scale: } 28 \text { days } \\
\text { 2. Artificially contaminated soil samples with crude oil }(2 \% \mathrm{w} / \mathrm{w}) \text { were used } \\
\text { 3. Target contaminant: TPHs } \\
\text { 4. } \\
\text { Extracting solvent for TPHs: Dichloromethane }\end{array}$ & $\begin{array}{l}\text { Temperate } \\
\text { climate }\end{array}$ & $\begin{array}{l}>\quad \begin{array}{l}\text { Highlighted that time is factor on remediation } \\
\text { efficiency }\end{array} \\
>\quad \text { Highest remediation efficiency was } 95 \% \text { with A. } \\
\text { niger after } 28 \text { days of treatment. } \\
\text { Highest remediation efficiency by mixed cultures } \\
\text { of fungi were } 90 \% \text { with A. niger and A. fumigatus. }\end{array}$ \\
\hline 6. & Fana $^{74}$ & $\begin{array}{l}\text { Yeast- Candida tropicalis SK2 } \\
\text { (all microscopic) }\end{array}$ & $\begin{array}{l}\text { 1. Laboratory/glasshouse Scale:180days } \\
\text { 2. Typical petroleum contaminated-soil samples with crude oil } \\
\text { 3. The Candida tropicalis SK21 was inoculated into the soil to reach a } \\
\text { density of } 1.0 \times 106 \mathrm{CFU} / \mathrm{g} \text {. } \\
\text { 4. Target contaminant: TPHs and PAHs } \\
\text { Extracting solvent for TPHs: Dichloromethane }\end{array}$ & $\begin{array}{l}\text { Temperate } \\
\text { climate }\end{array}$ & $\begin{array}{l}\text { Microbial enumeration showed that the yeast SK21 } \\
\text { could grow well in the contaminated soil } \\
\text { Yeast removed } 83 \% \text { of TPH in } 180 \text { days } \\
81.5 \% \text { of PAHs were removed by the fungi during } \\
\text { the period of } 180 \text { days }\end{array}$ \\
\hline
\end{tabular}




\begin{tabular}{|c|c|c|c|c|c|c|}
\hline 7. & Rahman $^{10}$ & $\begin{array}{l}\text { Oyster mushroom } \\
\text { (macroscopic) }\end{array}$ & $\begin{array}{ll}\text { 1. Laboratory /glasshouse Scale: } 31 \text { days } \\
2 . \quad \text { Artificially contaminated soil samples with crude oil were used } \\
\text { 3. Layer of oyster mushrooms substrate were equally distributed on } \\
\text { top of the soil and gently compacted }\end{array}$ & $\begin{array}{l}\text { Temperate } \\
\text { climate }\end{array}$ & & $\begin{array}{l}>\quad \text { Fruit bodies of mushroom was found } 7 \text { days } \\
\quad \text { after inoculation } \\
>\quad 35 \% \text { of TPH was removed }\end{array}$ \\
\hline 8. & Abioye $^{56}$ & $\begin{array}{l}\text { Yeast-Saccharomyces cerevisiae } \\
\text { (microscopic) }\end{array}$ & $\begin{array}{l}\text { 1. Laboratory /glasshouse Scale: } 28 \text { days } \\
\text { 2. crude oil samples ( } 3.5 \text { and } 7.0 \% \text { ) } \\
\text { 3. Yeast was isolated from Zobo drink and developed on Sabauroud } \\
\text { dextrose agar by spread plate method incubated at } 25^{\circ} \mathrm{C} \text { for } 48 \text { hours. } \\
\text { 4. Cultured yeasts were then inoculated on a } 50 \mathrm{ml} \text { Mineral salt medium } \\
\text { containing } 1 \mathrm{~g} \text { of crude oil and maintained at } 30^{\circ} \mathrm{C} \text { for } 28 \text { days } \\
\text { 5. Target contaminants: TPHs } \\
\text { 6. Solvent for extraction: Dimethyl ether }\end{array}$ & Tropical climate & $\vec{\nu}$ & $\begin{array}{l}\text { Degradation activities increased with days } \\
49.29 \% \text { of crude oil degradation was achieved } \\
\text { after } 28 \text { days. }\end{array}$ \\
\hline 9. & Al-Nasrawi ${ }^{57}$ & $\begin{array}{l}\text { 1. Aspergillus niger } \\
\text { 2. Penicillium documbens, } \\
\text { 3. Cochliobolus lutanus } \\
\text { 4. Fusarium solani. } \\
\text { (all microscopic) }\end{array}$ & $\begin{array}{l}\text { 1. Laboratory /glasshouse Scale: } 21 \text { days } \\
\text { 2. Typical petroleum-contaminated soils taken from } 0-15 \mathrm{~cm} \text { of } \\
\text { contaminated sites were used } \\
\text { 3. Prepared fungi on nutrient medium were used to inoculates soils and } \\
\text { maintained at } \\
\text { 4. Extracting solvent: acetone and dichloromethane (DCM)-1:1 } \\
\text { 5. Target contaminants: PAHs } \\
\text { Method of application: Layering growing substrates on top of soil }\end{array}$ & $\begin{array}{l}\text { Temperate } \\
\text { climate }\end{array}$ & $>$ & $\begin{array}{l}\text { Highest degradation was recorded for Pennicillin } \\
\text { documbens at } 21 \text { days. }\end{array}$ \\
\hline 10. & Edema $^{75}$ & $\begin{array}{l}\text { Basidiomycetes } \\
\text { (macroscopic) }\end{array}$ & $\begin{array}{l}\text { 1. Laboratory/glasshouse Scale: } 4 \text { weeks } \\
\text { 2. Artificially contaminated soils (soils thoroughly mixed with crude oil } \\
\quad 1 / / 5.0 \mathrm{Kg} \text { ). } \\
\text { 3. Extracting solvent: acetone and dichloromethane (DCM)-1:1 } \\
\text { 4. Target contaminants: PAHs } \\
\text { Method of application: Layering growing substrates and active spawn on top } \\
\text { of soil }\end{array}$ & Tropical climate & $>$ & 98.93\% PAHs reduction was achieved \\
\hline 11. & Kristanti 67 & $\begin{array}{l}\text { Polyporus sp } \\
\text { (macroscopic) }\end{array}$ & $\begin{array}{l}\text { 1. Laboratory/glasshouse Scale: } 60 \text { days } \\
\text { 2. Artificially contaminated soils with crude oil( } 3000 \mathrm{mg}) \\
\text { 3. Extracting solvent: hexane, dichloromethane (DCM) and chloroform } \\
\text { successively } \\
\text { 4. Target contaminants: TPHs } \\
\text { Method of application: wood meal pre-grown fungi were applied to } \\
\text { contaminated soil surface, then mixed thoroughly }\end{array}$ & $\begin{array}{l}\text { Temperate } \\
\text { climate }\end{array}$ & $>$ & $\begin{array}{l}\text { highest degradation rate of crude oil was } 93 \% \text { in } \\
\text { the soil after } 60 \text { days }\end{array}$ \\
\hline 12. & Adenipekun ${ }^{15}$ & $\begin{array}{l}\text { Pleurotus pulmonarius } \\
\text { (macroscopic) }\end{array}$ & $\begin{array}{l}\text { 1. Laboratory /glasshouse Scale: } 2 \text { months } \\
\text { 2. Artificially contaminated soils with crude oil and Palm kernel oil (0- } 40 \%) \text {. } \\
\text { 3. Target contaminants : Total Petroleum Hydrocarbons (TPHs) } \\
\text { Method of application: Layering growing substrates and active spawn on top } \\
\text { of soil }\end{array}$ & Tropical climate & $\vec{\nu}$ & $\begin{array}{l}\text { trace metal contents decreased during treatment } \\
\text { There was a } 40.80 \% \text { degradation of TPHs at } 1 \% \\
\text { crude oil concentration and } 9.28 \% \text { at } 40 \% \text { after } 2 \\
\text { months. }\end{array}$ \\
\hline 13. & Adenipekun ${ }^{76}$ & $\begin{array}{l}\text { Lentinus subnudus } \\
\text { (macroscopic) }\end{array}$ & $\begin{array}{l}\text { 4. Laboratory /glasshouse Scale: } 3-6 \text { months } \\
\text { 5. Artificially contaminated soils (soils thoroughly mixed with crude oil } \\
\text { concentrations }(0,1,2.5,5,10,20 \text { and } 40 \% \text { ). } \\
\text { 6. Target contaminants : Total Petroleum Hydrocarbons (TPHs) } \\
\text { 7. Method of application: Layering growing substrates and active spawn on } \\
\text { top of soil }\end{array}$ & Tropical climate & $>$ & $\begin{array}{l}\text { Total Petroleum Hydrocarbon decrease were } \\
33.04 \%, 56.67 \%, 14.85 \%, 25.27 \%, 22.57 \% \text { and } \\
15.25 \% \text { respectively for each concentration after } \\
3 \text { months, and } \\
60.60 \%, 78.25 \%, 85.64 \%, 89.54 \%, 95.12 \% \text { and } \\
95.12 \% \text { respectively after } 6 \text { months }\end{array}$ \\
\hline
\end{tabular}




\begin{tabular}{|c|c|c|c|c|c|}
\hline 14. & Stamets $^{2}$ & $\begin{array}{l}\text { Pleurotus ostreatus } \\
\text { (macroscopic) }\end{array}$ & $\begin{array}{l}\text { 1. Large Scale: } 8 \text { weeks } \\
\text { 2. Typical petroleum- contaminated soils of diesel and oils approximately } \\
20,000 \text { parts per million of Total Aromatic Hydrocarbons } \\
\text { 3. } 4 \text { piles of contaminated soils where place on a large sheet of } 6 \mathrm{~mm} \text { black } \\
\text { polythene tarps. Each pile measured about } 4 \times 20 \times 8 \text { feet in width } \\
\text { 4. A corresponding } 30 \% \text { of sawdust spawns were mixed to contaminated } \\
\text { soils. } \\
\text { 5. Spawn where placed in layers between contaminated soils in a parallel } \\
\text { 6. sheet spawning }\end{array}$ & $\begin{array}{l}\text { Temperate } \\
\text { Climate }\end{array}$ & $>\quad$ About $99 \%$ of TPHs were degraded after 8 weeks \\
\hline 15. & Isikhuemhen 62 & $\begin{array}{l}\text { Pleurotus tuberregium } \\
\text { (macroscopic) }\end{array}$ & $\begin{array}{l}\text { 1. Laboratory /glasshouse Scale: } 30 \text { days } \\
\text { 2. Artificially contaminated soils }(1,3,5,10 \text { and } 15 \%, \mathrm{w} / \mathrm{w}) \text { of crude oil } \\
\text { 3. Target contaminants: } \mathrm{TPHs} \\
\text { 8. Solvent for extraction: } \mathrm{Xylene} \\
\text { Method of application: } \mathrm{mixing} \text { contaminated soils with substrates, then } \\
\text { inoculation active spawn }(25 \% \mathrm{w} / \mathrm{w})\end{array}$ & Tropical climate & $>\quad$ There was $85 \%$ reduction in TPHs after 30days \\
\hline
\end{tabular}

(Many other studies exist on mycoremediation of organic/ inorganic contaminants. In preparing this table emphasis was on soil contaminants directly relating to crude oil/petroleum products. Where similar studies-involving similar fungi and identical scenarios/outcomes existed, only one of such was taken as a representative case based on a 'first published' criteria). 


\section{Mechanism of mycoremediation}

The mechanism of fungal degradation of organic contaminants in soils is presently thought to follow a similar mechanism for degradation of lignin $32,77,78$. Several mechanisms have been proposed including both direct and indirect oxidation of the organic molecule by the fungal enzymes namely Lignin-peroxidase (LiP), Manganese Peroxidase (MnP) (Figure 1), Versatile peroxidase (VP) and Lacasses $52,79,80$. Hatakka 81 suggested a possible combination of two or more enzyme mechanisms in the degradation process. Hofrichter 82 proposed a radicalmediated reaction initiated by manganese peroxidase (MnP). This involves indirect oxidation of aromatic (phenolic) rings (ether peroxide formation), spontaneous ring opening to produce muconic acid derivatives and decarboxylation of the formed carboxyl groups to carbon dioxide 83 . Several intermediate fragments are produced in the processes (Figure 1).

\section{Application procedures for mycoremediation of petroleum-contaminated soils}

The general procedure for application of mushrooms to contaminated soils is by layering8486. This has been carried out by layering actively growing substrates on topsoil or by way of vertical and horizontal sandwiching of active mushroom substrates between contaminated soils 2,70 . The actively growing mushrooms substrates may be pre-developed to a level where mycelia are actively sprouting before inoculation of soils, or spawns may be inoculated directly on substrates layered on soils 76,87 .

Adenipekun 70 described a procedure whereby $400 \mathrm{~g}$ of soils was artificially contaminated with $0-30 \%$ of spent cutting fluid-SCF and fresh cutting fluids-FCF and placed in sterile $350 \mathrm{ml}$ bottles. $80 \mathrm{~g}$ of moistened rice straw were then laid on these soils, and after sterilization and cooling, $10 \mathrm{~g}$ of the actively growing mushrooms spawns were inoculated on the samples. In Bhatt $87,250 \mathrm{~g}$ of contaminated soil was placed between two layers of rice straw colonized with fungal mycelium (i.e. $50 \mathrm{~g}$ of the fungal mycelium on top and $50 \mathrm{~g}$ at bottom of the soil). For microscopic fungi, these are often prepared first on their respective growth media before inoculation on soils $57,73,74$. 


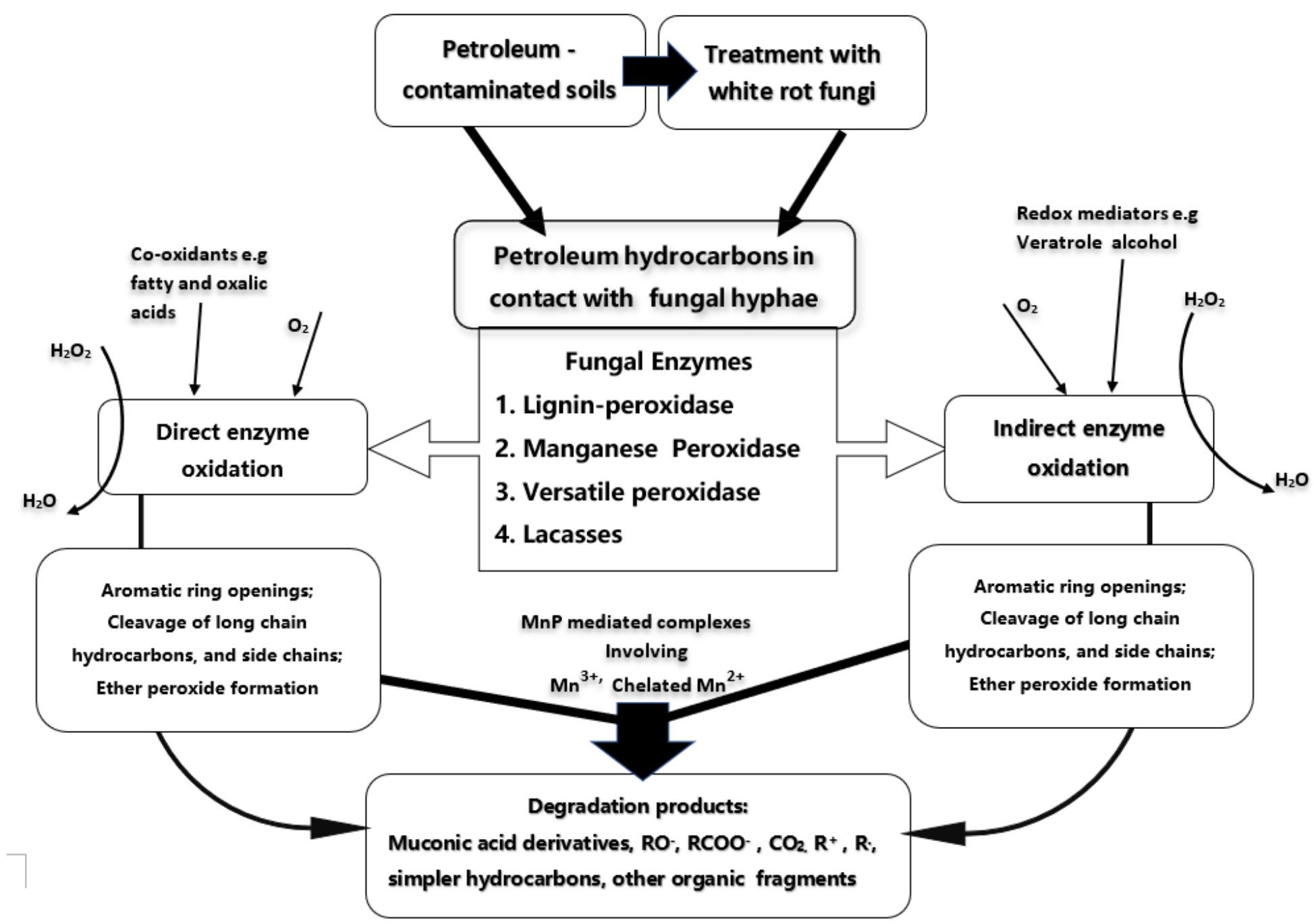

Figure 1: Mechanism of mycoremediation of petroleum-contaminated soil by white rot fungi 


\section{Substrates for mycoremediation of contaminated soils}

Substrates that have been used for growing white-rot fungi include rice straw, cotton waste, wheat bran, rice bran, shredded straw, corn cobs, soybeans flour, pasteurized/fermented/fresh cereal straw, pine barks, fragmented woods (sawdust), straw bales, sugar beet pulps and coffee pulps 88,89 . These substrates are often enriched with animal manures in different proportions for effective growth60,90. Composting has also been used as soil amendment for mycoremediation 91 . Wright 92 demonstrated an overall degradation of PAHs between 80 and $92 \%$ in contaminated soils treated with spent sawdust compost.

Substrates for mycoremediation of petroleum contaminated soils are also usually sterilized before inoculation of the fungal spawns 2,15 . Adenipekun70 reported that sterilization of fungal substrates reduces competition by other microbial organisms which could inhibit the growth of the mushrooms.

\section{Advances in mycoremediation of petroleum contaminated soils}

Studies on mycoremediation have evolved from the direct use of fungi and mushrooms, to that of fungal-derived enzymes as well as spent fungal substrates $84-86,94$. These studies have also been carried out both in situ and ex situ, and there are a some large-scale applications 94,95 . There are also reports on mycoremediation in both temperate and tropical regions (Table 1), as well as in developed and developing countries $2,59,75,96,97$. It has further been demonstrated that a combination of fungi and bacteria can lead to enhanced remediation efficiency 98 .

Studies such as Aranda99, Hirantsuka100 and Sack ${ }^{101}$ have demonstrated that fungal enzyme extracts can degrade organic contaminants in soils. Anasonye 96 however, reported that MnP-enzyme extracts of the fungus Kuehneromyces mutabilis could not replicate the activity exhibited by the fungi itself on contaminated soils. These observations support the proposition of Hatakka 81 who stated that a combination of more enzyme systems and other physiological processes are involved in the mycoremediation process. 
Winquist 97 demonstrated that laboratory outcomes of mycoremediation can also be applied in the field. PAHs-contaminated soils were mixed with composted green waste (1:1) and treated with fungal inoculum of Phanerochaete velutina. The study was performed both at the laboratory and field scales. Results from laboratory study with an initial concentration of $3500 \mathrm{mg} / \mathrm{kg}$ revealed up to $96 \%$ degradation of 4 -ring PAHs and $39 \%$ of 5- and 6-ring PAHs after three months. For the field study with an initial PAHs concentration of $1400 \mathrm{mg} / \mathrm{kg}$ of soil, $94 \%$ of the 16 PAHs were degraded after three months. Okparanma ${ }^{102}$, Zitte 103 and Albert 104 have also demonstrated that spent mushroom substrates could be used for mycoremediation of petroleum contaminated soils.

\section{DISCUSSION}

Most studies of mycoremediation of petroleum-contaminated soils are carried out using artificially contaminated soils in glasshouses, under sterile conditions 10,56 . This could lead to several issues in applying laboratory results to the field.

Firstly, the varying concentrations added to soils to create artificial contamination cannot be compared to real crude oil spills with massive quantities of petroleum contaminants in soils. Liu105 reported up to $50 \%$ content of total petroleum hydrocarbons per $\mathrm{Kg}$ dry soil in petroleum contaminated sites. Concentrations of up to $420 \mathrm{~g} / \mathrm{kg}$ of total petroleum hydrocarbons were also reported by Kim 106 . Thus, it would be ideal to use typical petroleumcontaminated soils during mycoremediation studies. The use of typical petroleumcontaminated soils such as those of $\operatorname{Kim}^{106}$ would allow potential incorporation of measures for possible dilution of highly contaminated soils prior to application of mycoremediation 107 . Secondly, the aspect of substrates sterilization and incubation at room temperatures creates an artificial environment which is different from those of the field during in situ applications. Using unsterilised substrates and conditions identical to field environments would aid replication of laboratory outcomes in the field.

Thirdly, climatic and edaphic factors are not usually incorporated into laboratory or glasshouse studies and this will certainly be encountered in the natural environment. Ideal research in mycoremediation of petroleum-contaminated soils should be tailored towards real-life situations using typical petroleum-contaminated soils and unsterilised conditions. 
This would involve investigations into various substrates and conditions which can be easily replicated during in situ applications. Using substrates and fungi species which are ubiquitous or native to sites of contamination would also help mitigate potential adaptation problems.

There seem to be limited reports on application of enhancement agents such as the use of surfactants, combination with other microbial communities, as well as combinations of mycoremediation with phytoremediation for treatment of petroleum contaminated soils. Surfactants can increase the bioavailability of organic contaminants 108,109 . Therefore, integrating surfactants with mycoremediation, and combination with other biological agents could lead to increase efficiency of the process on petroleum contaminated soils.

Biotechnology and engineering solutions are not often incorporated into mycoremediation for the management of petroleum contaminated soils. Bamforth 110 and D'Annibale ${ }^{35}$, reported that factors such as life cycle, size of fruity body and mycelium biomass influence the efficiency of mycoremediation. Biotechnology can be integrated to developed mushrooms with better size of the fruity body, mycelium biomass and improved enzyme yield111,112, which will result in increased mycoremediation efficiency.

Although many studies exist supporting the potential of mycoremediation of soil contaminants (organic and inorganic), only few of such studies relate to soil contamination by crude oil and other petroleum products. Most of the studies so far carried out on mycoremediation of petroleum-contaminated soils are still at laboratory or glasshouse scale. There is a need to initiate research that applies glasshouse findings to field applications.

\section{CONCLUSION}

Mycoremediation is also capable of providing reliable options for the treatment of petroleumcontaminated soils. This is because fungi can provide cheaper and safer means for the simultaneous degradation of organic contaminants and the extraction of inorganic species. In addition, most fungi are ubiquitous which ensures their widespread applications. Furthermore, the warm temperatures for fungal growth makes the technique ideal for tropical regions with warm temperatures, locally available fungi and substrates.

There are several innovations in this field, notably, the use of fungal enzymes, and spent mushroom substrates. These provide options in situations where mushrooms cannot be 
cultivated. Petroleum-contaminated sites often also contain high levels of trace metals. Most of the mushroom species are hyperaccumulators of trace metals. It is therefore worth not only studying their degradation or extraction efficiencies but possible speciation and transformation of the inorganic (trace metals) species. Mushrooms have short life cycles, which is somewhat an advantage, because a remediation cycle can be achieved within a short time. However, care must be taken such that substances already taken up are not returned to soils via putrefaction. The end use and treatment of the harvested mushrooms should also be integrated into remediation programs.

Finally, the challenge in the development of mycoremediation from laboratory studies to large-scale field applications on petroleum-contaminated soils lies in incorporating ideal environmental, edaphic and climatic factors of a typical contaminated site into the process from first principles.

\section{REFERENCES}

1. P. Baldrian, J. Gabriel, F. Nerud and F. Zadražil. Influence of cadmium and mercury on activities of ligninolytic enzymes and degradation of polycyclic aromatic hydrocarbons by Pleurotus ostreatus in soil. Applied Environmental Microbiology. 2000; 66(6):2471-8.

2. P. Stamets. Mycelium running: how mushrooms can help save the world. Random House, Inc. 2005, . pp. 83-84.

3. F. Acevedo, L. Pizzul, M. del Pilar Castillo, R. Cuevas, M. C. Diez. Degradation of polycyclic aromatic hydrocarbons by the Chilean white-rot fungus Anthracophyllum discolor. Journal of hazardous materials. 2011; 185(1):212-9.

4.M. Thakur. Mycoremediation-a potential tool to control soil pollution. Asian Journal of Environmental Sciences. 2014; 9(1): 21-31.

5. S. Kulshreshtha, N. Mathur and P. Bhatnagar. Mushroom as a product and their role in mycoremediation. AMB Express. 2014; 4: 29.

6. C. Anderson, G. Juday. Mycoremediation of Petroleum: A Literature Review. Journal of Environmental Science and Engineering A. 2016; 5: 397-405.

7. D. Loske, A. Huttermann, A. Majerczk, F. Zadrazil, H. Lorsen and P. Waldinger. Use of white rot fungi for the clean-up of contaminated sites. In: Advances in biological treatment of lignocellulosic materials (Ed.). M. P. Coughlan and Collaco, Elsevier, London, 1990, pp.311 321. 
8. F. I. Khan, T. Husain and R. Hejazi. An Overview and Analysis of Site Remediation Technologies. Journal of Environmental Management. 2004; 71: 95-122.

9. V. Leonardi, V. Sasek, M. Petruccioli, A. D’Annibale, P. Erbanova and T. Cajthaml. Bioavailability modification and fungal biodegradation of PAHs in aged industrial soils. International Journal of Biodeterioration \& Biodegradation. 2007; 60 (3): 165-170.

10. F. A. Rahman, R. Rafati, R., N. M. Affandi, W. Jamiah, H. Hamid and M. Zulkifili. The application of wild mushrooms in controlling the amount of crude oil in polluted environments. Proceedings of SPE Asia pacific oil and gas conference and exhibition, APOGCE: Maximising the mature, elevating the Young. 2013:1359-1363.

11. K.E. Hammel. Organo-pollutants degradation by ligninolytic fungi. Enzyme and Microbial Technonology. 1989;11: 776-777.

12. T. Eggen and A. Majcherczyk. Removal of polycyclic aromatic hydrocarbons (PAH) in contaminated soil by white-rot fungus, Pleurotus ostreatus. International of Biodeterioration \& Biodegradation. 1998; 41 (2): 111-117.

13. A. K. Haritash and C. P. Kaushik. Biodegradation aspects of polycyclic aromatic hydrocarbons (PAHs): A review. Journal of Hazardous Materials. 2009; 169 (1-3): 1-15.

14. N. U. Asamudo, A. S. Daba and O. U. Ezeronye. Bioremediation of textile effluent using Phanerochaete chrysosporium. African Journal of Biotechnology. 2005; 4:1548-1553

15. C. O. Adenipekun and Y. Lawal. Mycoremediation of crude oil and palm kernel contaminated soils by Pleurotus pulmonarius Fries (Quelet). Nature and Science. 2011; 9(9):125-31.

16. D. Moore, G.D. Robson, A. P. Trinci. 21st century guidebook to fungi with CD. Cambridge University Press; 2011, pp 77-100.

17. D. L. Hawksworth. The fungal dimension of biodiversity: magnitude, significance and conservation. Mycological Research. 1991; 95:641-655.

18. E. Kiffer. The Deuteromycetes-Mitosporic Fungi: Classification and Generic Keys. CRC Press, New York, 2011, pp 2-77.

19. R. Maheshwari. Fungi: Experimental Methods In Biology, Mycology. CRC Press, New York, Second Edition. 2016; p. 3.

20. D. H. Griffin. Fungal physiology. John Wiley \& Sons; 1996, pp 1-12.

21. G. F. Leatham. Cultivation of shiitake, the Japanese forest mushroom, on logs: a potential industry for the United States. Forest Product Journal. 1982; 32(8):29-35.

22. J. Green. 1977. U.S. Patent No. 4,063,383. Washington, DC: U.S. Patent and Trademark Office.

23. D. J. Royse, and R. B. Beelman. Six steps to mushroom farming. http://mushroomspawn. cas. psu. edu/SixSteps. shtml. Assessed on 23/04/2019. 
24. D. P. Mamiro and D. J. Royse. The influence of spawn type and strain on yield, size and mushroom solids content of Agaricus bisporus produced on non-composted and spent mushroom compost. Bioresource technology. 2008; 99(8): 3205-3212.

25. L. Pathmashini, V. Arulnandhy, R. S. Wijeratnam. Efficacy of different spawn types on sawdust media. Tropical Agricultural Research and Extension. 2010; 11: 55-59.

26. S. Bhattacharya, J. Angayarkanni, A. Das. and M. Palaniswamy. Mycoremediation of Benzo[a]Pyrene by Pleurotus ostreatus isolated from Wayanad district in Kerala, India. International Journal of Pharmacy and Biological Sciences. 2012; 2 (2): 84-93.

27. H. T. Hoa, C. L. Wang and C. H. Wang. The Effects of Temperature and Nutritional Conditions on Mycelium Growth of Two Oyster Mushrooms (Pleurotus Ostreatus and Pleurotus Cystidiosus). Mycobiology. 2015; 43 (4): 423-34.

28. N. Aguilar-rivera, A. Moran and D. Arturo. "Production of Pleurotus Ostreatus (Oyster Mushroom ) Grown on Sugar Cane Biomass ( Trash , Bagasse and Pith )," no. 1. In L. Caccippo edited Food Science Research Biographical sketches and research summary. Nova publishers, New York, 2012, volume 1, pp 149-152.

29. N. C. Brady and R.R. Weil. Elements of the nature and properties of soils. Prentice Hall, Upper Saddle River, NJ, USA, 2000, pp 463-471.

30. T. F. Guerin. "The Differential Removal of Aged Polycyclic Aromatic Hydrocarbons from Soil during Bioremediation. Environmental Science and Pollution Research. 2000; 7 (1): 19-26

31. A. L. Amjad, G. U. Di, A. Mahar, W. A. Ping, S. H. Feng, L. I. Ronghua and Z. Zhang. Mycoremediation of potentially toxic trace elements-a biological tool for soil cleanup: $A$ review. Pedosphere. 2017; 27(2):205-22.

32. N. Das, and P. Chandran. Microbial Degradation of Petroleum Hydrocarbon Contaminants: An Overview. Biotechnology Research International. 2011; 1-13.

33. M. Kapahi and S. Sachdeva. Mycoremediation potential of Pleurotus species for heavy metals: a review. Bioresources and bioprocessing. 2017; 4(1), 32.

34. S. M. Bamforth and I. Singleton. Bioremediation of polycyclic aromatic hydrocarbons: current knowledge and future directions. Journal of Chemical Technology \& Biotechnology: International Research in Process, Environmental \& Clean Technology. 2005;80(7):723-36.

35. A. D'Annibale, F. Rosetto, V. Leonardi, F. Federici and M. Petruccioli. Role of autochthonous filamentous fungi in bioremediation of a soil historically contaminated with aromatic hydrocarbons. American Society of Microbiology. 2006; 72(1): 28-36.

36. S. J. Pollard, S. E. Hrudey, and P. M. Fedorak. Bioremediation of petroleum-and creosotecontaminated soils: a review of constraints. Waste Management \& Research. 1994; 12(2): 173-194.

37. R. Boopathy, and J. Manning. Surfactant-Enhanced Bioremediation of Soil Contaminated with 2, 4, 6-Trinitrotoluene in Soil Slurry Reactors. Water environment research. 1999; 71(1): 119-124. 
38. J. F. Mannig, R. Boopathy and C. F. Kulpa. A Laboratory Study in Support of the Pilot Demonstration of Biological Soil Slurry Reactor. ARGONNE NATIONAL LAB IL ENVIRONMENTAL RESEARCH DIV; 1995 Jul.

39. D. K. Singh, and H. C. Agarwal. Chemical release and nature of soil-bound DDT residues. Journal of Agriculture and Food Chemistry. 1992; 40:1713-1716.

40. T. Siddique, B. C. Okeke, M. Arshad and W. T. Frankenberger. Temperature and pH effects on biodegradation of hexachlorocyclohexane isomers in water and a soil slurry. Journal of agricultural and food chemistry. 2002; 50(18): 5070-5076.

41. J. Foght, T. April, K. Biggar and J. Aislabie. Bioremediation of DDT-contaminated soils: A review. Bioremediation Journal. 2001; 5(3): 225-246.

42. R. B. Owen, J.B. Dimond and A.S. Getchell. DDT: persistence in northern spodosols. Journal of Environmental Quality. 1977; 6:359-360.

43. L Boul, M. L. Garnham, D. Hucker, D. Baird, and J. Aislabie. Influence of agricultural practices on the levels of DDT and its residues in soil. Environmental Science and Technology. 1994; 28:1397-1402.

44. J. B. Dimond and R.B. Owen. Long-term residue of DDT compounds in forest soils in Maine. Environmental Pollution. 1996; 92:227-230.

45. Q. Hong, Z. Zhang, Y. Hong and S. Li. A microcosm study on bioremediation of fenitrothion-contaminated soil using Burkholderia sp. FDS-1. International biodeterioration \& biodegradation. 2007; 59(1): 55-61.

46. B. Xu, G. Jianying, Z. Yongxi, and L. Haibo. Behaviour of DDT in Chinese tropical soils. Journal of Environmental Science and Health. 1994; B29:37-46.

47. M.M Andrea, R. Y. Tomita, L. C. Luchini and M. R. Musumeci. Laboratory studies on volatilization and mineralization of $14 c-p, p^{\prime}-D D T$ in soil, release of bound residues and dissipation from solid surfaces. Journal of Environmental Science \& Health Part B. 1994; 29(1):133-9.

48. R. G. Nash, W.G. Harris, and C.C. Lewis. Soil pH and metallic amendment effects on DDT conversion to DDE. Journal of Environmental Quality. 1973; 2:390-394.

49. X. Xiao, H. Chen, C. Si and L. Wu. Influence of biosurfactant-producing strain Bacillus subtilis BS1 on the mycoremediation of soils contaminated with phenanthrene. International biodeterioration \& biodegradation. 2012; 75: 36-42.

50. L. Migliore, M. Fiori, A. Spadoni and E. Galli. Biodegradation of oxytetracycline by Pleurotus ostreatus mycelium: a mycoremediation technique. Journal of hazardous materials. 2012; 215, 227-232.

51. M. Singh, P. K. Srivastava, P. C. Verma, R. N. Kharwar, N. Singh and R. D. Tripathi. Soil fungi for mycoremediation of arsenic pollution in agriculture soils. Journal of applied microbiology. 2015; 119 (5): 1278-1290. 
52. E. B. Górska, J. Urszula, J. J. D. Dobrzyński, A. Gałązka, M. Sitarek, D. Gozdowski, S. Russel, and P. Kowalczyk. Production of Ligninolytic Enzymes by Cultures of White Rot Fungi. Polish Journal of Microbiology. 2014; 3(4): 461-465.

53. A. Seidu, A. K. Quainoo, G. Addae and K. Stenchly. Mycoremediation of diesel contaminated soil with oyster mushroom (Pleurotus ostreatus) using maize (Zea mays) as the test crop. UDS International Journal of Development. 2015; 2(2): 1-8.

54. N. Sood, S. Patle and B. Lal. Bioremediation of acidic oily sludge-contaminated soil by the novel yeast strain Candida digboiensis TERI ASN6. Environmental Science and Pollution Research. 2010; 17:603-610.

55. M. Kumari and J. Abraham. Biodegradation of Diesel Oil using Yeast Rhodosporidium toruloides. Research Journal of Environmental Toxicology. 2011; 5: 369-377.

56. O. P. Abioye, R. O. Akinsola, S. A. Aransiola, D. Damisa and S. H. Auta. Biodegradation of crude oil by saccharomyces cerevisiae isolated from fermented zobo (locally fermented beverage in Nigeria). Pakistani Journal of Biological Sciences. 2013; 16:2058-61.

57. H. Al-Nasrawi. Biodegradation of crude oil by fungi isolated from Gulf of Mexico. Journal of Bioremediation and Biodegradation. 2012;3(4):1-6.

58. A. A. El Hanafy, Y. Anwar, S. A. Mohamed, M. S. Al-Garni, J. S. Sabir, A. H. Osama and M. M. Zinadah. Isolation and Molecular Identification of Two Fungal Strains Capable of Degrading Hydrocarbon Contaminants on Saudi Arabian Environment. International Journal of Biological, Biomolecular, Agricultural, Food and Biotechnological Engineering. 2015; 9(12):1075-78.

59. C. J. Rhodes (2014). Mycoremediation (bioremediation with fungi) - growing mushrooms to clean the earth. Chemical Speciation \& Biology 26(3): 196-198.

60. O. Obire, E. Anyanwu and R. Okigbo. Saprophytic and Crude Oil Degradation Fungi from Caw Dung Dropping as Bioremediation Agents. International Journal of Agriculture Technology. 2008; 4(2): 81-89.

61. D. Miethe, V. Riis and M. Stimming. UFZ-Umweltforschungszentrum Leipzig-Halle GmbH, Leipzig (Germany). Sektion Umweltmikrobiologie;. Integrated project: Microbiological and physiological studies on the presence of residual concentrations in mineral-oilcontaminated soils after rehabilitation. Final report. Pt. 2; Mikrobiologische und physiologische Untersuchungen zur Frage der Restkonzentration bei der Sanierung mineraloelkontaminierter Boeden. Abschlussbericht. T. 2. 1996.

62. O. S. Isikhuemhen, G. O. Anoliefo and O. I. Oghale. Bioremediation of crude oil polluted soil by the white rot fungus, Pleurotus tuberregium (Fr.) Sing. Environmental Science and Pollution Research International. 2003; 10(2):108-12.

63. D. Gao, L. Du, J. Yang, W. Wu and H. Liang. A critical review of the application of white rot fungus to environmental pollution control. Critical Reviews in Biotechnology. 2010; 30(1): 7077. 
64. B. Fan, Y. Zhao, G. Mo, W. Ma and J. Wu. Co-remediation of DDT-contaminated soil using white rot fungi and laccase extract from white rot fungi. Journal of Soils Sediments. 2013; 13 : $1232-1245$.

65. S. E. Lebo, Jr., J. D. Gargulak, and T. J. McNally, Lignin, in Kirk-Othmer Encyclopedia of Chemical Technology, John Wiley \& Sons, Inc., New York, 2001, Vol. 15, pp. 1-32.

66. J. C. Fetzer. The Chemistry and Analysis of the Large Polycyclic Aromatic Hydrocarbons. Polycyclic Aromatic Compounds. Wiley, New York, 2000, 27, 2, pp 143-162.

67. R. A. Kristanti, T. Hadibarata, T. Toyama, Y. Tanaka, and K. Mori. Bioremediation of Crude Oil by White Rot Fungi Polyporus sp. Journal of Microbiology and Biotechnology. 2011; 21(9): 995-1000.

68. J. S. Davies and D. W. Westlake. Crude Oil Utilization by Fungi. Canadian Journal of Microbiology. 1979; 25 (2): 146-156.

69. M. Mohammadi-Sichani, M. M. Assadi, A. Farazmand, M. Kianirad, A. M. Ahadi and H. Hadian-Ghahderijani. Ability of Agaricus bisporus, Pleurotus ostreatus and Ganoderma lucidum compost in biodegradation of petroleum hydrocarbon-contaminated soil. International Journal of Environmental Science and Technology. 2018; 1-8.

70. C. O. Adenipekun, A. R. Ipeaiyeda, A. J. Olayonwa and S. O. Egbewale. Biodegradation of polycyclic aromatic hydrocarbons (PAHs) in spent and fresh cutting fluids contaminated soils by Pleurotus pulmonarius (Fries) Quelet and Pleurotus ostreatus (Jacq.) Fr. P. Kumm. African Journal of Biotechnology. 2015; 14(8):661-7.

71. O. I . Nicholas.. Bioremediation Potentials of Heterobasidion annosum 13.12B and Resinicium bicolor in Diesel Oil Contaminated Soil Microcosms. Journal of Applied Science and Environnemental Management. 2015; 19(3): 513-519.

72. D. Young, J. Rice, R. Martin, E. Windquist, A. Lipzen, A. Grigoriev and D. Hibbett. Degradation of Bunker C Fuel Oil by White-Rot Fungi in Sawdust Cultures Suggests Potential Applications in Bioremediation. PLOS ONE. 2015; 10(6): 1-15.

73. I. Flayyih and H. Al-Jawhari. Ability of some Soil Fungi in Biodegradation of Petroleum Hydrocarbon. Journal of Applied \& Environmental Microbiology. 2014; 2 (2): 46-52.

74. Y. Fana, R. Xie and G. Qin. Bioremediation of petroleum contaminated soil by a combined system of biostimulation-bioaugmentation with yeast. Environmental Technology. 2014; 35(4): 391-399.

75. C. U. Edema, T. E. Idu and M. O. Edema. Remediation of soil contaminated with polycyclic aromatic hydrocarbons from crude oil. African Journal of Biotechnology. 2011;10(7):1146-9.

76. C. O. Adenipekun and I. O. Fasidi. Bioremediation of oil-polluted soil by Lentinus subnudus, a Nigerian white-rot fungus. African journal of biotechnology. 2005;4(8):796-8.

77. D. P. Barr and S. D. Aust. Mechanisms white rot fungi use to degrade pollutants. Environmental Science \& Technology. 1994;28(2):78A-87A. 
78. C. Novotny, K. Svobodova, P. Erbanova, T. Cajthaml, A. Kasinath, E. Lange and V. Sasek. Ligninolytic fungi in bioremediation: extracellular enzyme production and degradation rate. Soil Biology \& Biochemistry. 2004; 36(10): 1545-1551.

79. R. T. Have and P. J. M. Teunissen. Oxidative Mechanisms Involved in Lignin Degradation by White-Rot Fungi. Chemical Reviews. 2001; 101, 3397-3413.

80. V. Christian, R. Shrivastava, D. Shukla, H. A. Modi and B. R. M. Vyas. Degradation of Xenobiotic Compounds by Lignin-degrading White-rot Fungi: Enzymology and Mechanisms involved. Indian Journal of Experimental Biology. 2005; 43:301-312.

81. A. Hatakka. Lignin-modifying enzymes from selected white-rot fungi - production and role in lignin degradation. FEMS Microbiology Reviews. 1994; 13:125-13.

82. M. Hofrichter. Review: lignin conversion by manganese peroxidase (MnP). Enzyme and Microbial Technology. 2002; 30: 454-466.

83. W. Fritsche and M. Hofrichter. Aerobic degradation of recalcitrant organic compounds by microorganisms. Environmental Biotechnology Concepts and Applications. John Wiley \& Sons. 2005. Pp 223.

84. V. Sasek. Why mycoremediation have not yet come into practice. In: The utilization of bioremediation to reduce soil contamination: problems and solution, Kluwer Academic Publishers, Amsterdam, 2003, pp.247-266.

85. V. Elisashavili, E. Kachlishvili and M. J. Penninckx. Lignocellulolytic Enzymes Profile During Growth and Fruiting of Pleurotus ostreatus on Wheat Straw and Tree Leaves. Acta Microbiologica et Immunologica Hungarica, 2008; 55 (2): 157-168.

86. A. D. Singh, S. Vikineswary, N. Abdullah and M. Sekaran. Enzymes from spent mushroom substrate of Pleurotus sajor-caju for the decolourisation and detoxification of textile dyes. World Journal of Microbiology and Biotechnology. 2011;27(3):535-545.

87. M. Bhatt, T. Cajthaml and V. Sasek. Mycoremediation of PAH-contaminated soil. Folia Microbiologica; Dordrecht. 2002; 47(3) : 255-8.

88. C. Rolz, R. De Leon and M. C. De Arriola. Solid substrate growth of white rot fungi on coffee pulp. Acta Biotechnologica. 1988; 8(3):211- 223.

89. F. Zadrazil and P. Reiniger. Treatment of Lignocellulosics with White Rot fungi. Elsevier Applied Science publisher Ltd, Essex, United Kingdom, 1998, Pp1-14.

90. T. P. Nwogu, C. C. Azubuike and C. J. Ogugbue. Enhanced Bioremediation of Soil Artificially Contaminated with Petroleum Hydrocarbons after Amendment with Capraae gagrushircus (Goat) Manure. Biotechnology Research International. 2015:7:1-7.

91. Z. Zeng, X. Guo, P. Xu, R. Xiao, D. Huang, X. Gong, ... and G. Zeng, G. Responses of microbial carbon metabolism and function diversity induced by complex fungal enzymes in lignocellulosic waste composting. Science of The Total Environment. 2018; 643:539-547. 
92. C. Wright, A. P. Gryganskyi and G. Bonito. Fungi in composting. In Fungal Applications in Sustainable Environmental Biotechnology, Springer, Cham, 2016, pp. 3-28.

93. F. Giraud, P. Guiraud, M. Kadri, G. Blake and R. Steiman. Biodegradation of Anthracene and Fluoranthene by Fungi Isolated from an Experimental Constructed Wetland for Wastewater Treatment. Water Research. 2001;35 (17): 4126-46.

94. J. Zhou, W. Jiang, J. Ding, X. Zhang and S. Gao. Effect of Tween 80 and beta-cyclodextrin on degradation of decabromodiphenyl ether (BDE-209) by white rot fungi. Chemosphere. 2007; 70(2):172-177.

95. O. H. Zebulun, O. S. Isikhuemhen and I. Hilary. Decontamination of anthracene-polluted soil through white rot fungus- induced biodegradation. Environmentalist. 2011; 31: 11-19.

96. F. Anasonye, E. Winquist, B. Kluczek-Turpeinen, M. Räsänen, K. Salonen, K. T. Steffen and M. Tuomela. Fungal enzyme production and biodegradation of polychlorinated dibenzo-pdioxins and dibenzofurans in contaminated sawmill soil. Chemosphere. 2014;110:85-90.

97. E. Winquist, K. Björklöf, E. Schultz, M. Räsänen, K. Salonen, F. Anasonye, T. Cajthaml, K. T. Steffen, K. S. Jørgensen and M. Tuomela. Bioremediation of PAH-contaminated soil with fungi - from laboratory to field scale. International Biodeterioration \& Biodegradation. 2014; 86: $238-247$.

98. L. Chen, W. Chen, L. Chen and Y. Chen. Study on Fungi-Bacteria Augmented Remediation of Petroleum Contaminated Soil from Northwest of China. Journal of Food, Agriculture and Environment. 2009; 7 (3-4. pt. 2):750-753.

99. E. Aranda, R. Ullrich and M. Hofrichter. Conversion of polycyclic aromatic hydrocarbons, methyl naphthalenes and dibenzofuran by two fungal peroxygenases. Biodegradation. 2010;21(2):267-81.

100. N. Hiratsuka, M. Oyadomari, H. Shinohara, H. Tanaka and H. Wariishi. Metabolic mechanisms involved in hydroxylation reactions of diphenyl compounds by the lignindegrading basidiomycete Phanerochaete chrysosporium. Biochemical Engineering Journal. 2005; 23: 241-246.

101. U. Sack, M. Hofrichter and W. Fritsche. Degradation of polycyclic aromatic hydrocarbons by manganese peroxidase of Nematoloma frowardii. FEMS Microbiological Letters. 1997; (152): 227-234.

102. R. N. Okparanma, J. M. Ayotamuno, D. D. Davis and M. Allagoa. Mycoremediation of polycyclic aromatic hydrocarbons (PAH)-contaminated oil-based drill-cuttings. African Journal of Biotechnology. 2011; 10(26):5149- 5156.

103. L. F. Zitte, G. D.B. Awi-Waadu and A. U. John. Effect of Oyster Mushroom (Pleurotus Ostreatus) Mycelia on Petroleum Hydrocarbon Contaminated Substrate. Journal of Agriculture and Social Research (JASR). 2012; 12(2): 115. 
104. E. Albert and D .I. Anyanwu. Evaluation of Composting with 'Spent'Mushroom Substrate and Sawdust for Remediation of Petroleum Hydrocarbon-Polluted Soil. Soil. Journal of Agriculture and Ecology Research International. 2016; 9(1): 1-9.

105. R. Liu, R. N. Jadeja, Q. Zhou and Z. Liu. Treatment and remediation of petroleumcontaminated soils using selective ornamental plants. Environmental engineering science. 2012; 29(6): 494-501

106. N. Kim, K. Kwon, J. Park, J. Kim, J.W. Choi. Ex situ soil washing of highly contaminated silt loam soil using core-crosslinked amphiphilic polymer nanoparticles. Chemosphere. 2019; 224:212-9.

107. S. A. Olusola and E. E. Anslem. Bioremediation of a crude oil polluted soil with Pleurotus pulmonarius and Glomus mosseae using Amaranthus hybridus as a test plant. Journal of Bioremediation and Biodegradation. 2010; 1: 113.

108. M. Pacwa-Płociniczak, G. A. Płaza, Z. Piotrowska-Seget and S. S. Cameotra. Environmental applications of biosurfactants: recent advances. International Journal of molecular sciences. 2011; 12(1): 633-654.

109. C. Liao, W. Xu, G. Lu, F. Deng, X. Liang, C. Guo and Z. Dang. Biosurfactant-enhanced phytoremediation of soils contaminated by crude oil using maize (Zea mays. L). Ecological Engineering. 2016, 92: 10-17.

110. S. M. Bamforth and I. Singleton. Bioremediation of polycyclic aromatic hydrocarbons: current knowledge and future directions. Journal of Chemical Technology \& Biotechnology. 2005; 80(7): 723-736.

111. S. Ohga and Y. Kitamoto. Future of mushroom production and biotechnology. Food Reviews International. 1997; 13(3):461-469.

112. T. E. Tautorus and P. M. Townsley. Biotechnology in commercial mushroom fermentation. Biotechnology. 1984; 2(8): 696. 